\title{
Selectivity of pesticides used in peach orchards to eggs and pupae of the predators Chrysoperla externa and Coleomegilla quadrifasciata
}

\author{
Seletividade de produtos fitossanitários utilizados na cultura do \\ pessegueiro a ovos e pupas dos predadores Chrysoperla externa e \\ Coleomegilla quadrifasciata
}

\author{
Franciele Silva de Armas ${ }^{1}$; Anderson Dionei Grützmacher²; Dori Edson Nava ${ }^{3}$; \\ Matheus Rakes ${ }^{4 *}$; Flávio Amaral Bueno ${ }^{4}$; Rafael Antonio Pasini ${ }^{5}$
}

\begin{abstract}
This study aimed to assess, under laboratory conditions, the selectivity of nine pesticides used in peach to the egg and pupal stages of the predators Chrysoperla externa and Coleomegilla quadrifasciata. Tests consisted of the direct application of pesticides on eggs and pupae of predators and assessment of sublethal effects on fertility and fecundity of emerged adults. For eggs, the pesticides were classified according to the effects on the reduction of the percentage of larval hatching, while for pupae they were classified as a function of the total effect, according to the toxicity scale proposed by the International Organization for Biological and Integrated Control (IOBC). All the pesticides (used dose) were harmless (class 1 ) to eggs of $C$. externa, but abamectin (80) and copper + calcium (1\%) were considered slightly harmful (class 2) to pupae. In bioassays with C. quadrifasciata, abamectin (80), deltamethrin (40), and malathion (150) were classified as slightly harmful (class 2), while fenitrothion (100) was moderately harmful (class 3) to predator eggs; in the pupal stage, abamectin (80), fenitrothion (100), and malathion (150) were considered harmful (class 4). Azadirachtin (1\%), chlorantraniliprole (14), deltamethrin (40), copper + calcium $(25 \%+10 \%)$, and sulfur + calcium $(3.5 \mathrm{Ba})$ were harmless (class 1$)$ to eggs and pupae of C. externa and C. quadrifasciata and thus should be prioritized in sprayings for pest control in the IPM of peach.
\end{abstract}

Key words: Green lacewing. Ladybug. Fruticulture. Chemical control. Integrated pest management.

\section{Resumo}

Objetivou-se com este trabalho avaliar em laboratório a seletividade de nove produtos fitossanitários utilizados na cultura do pessegueiro sobre as fases de ovo e pupa dos predadores Chrysoperla externa e Coleomegilla quadrifasciata. Os ensaios consistiram da aplicação direta dos agrotóxicos sobre ovos e pupas dos predadores e avaliação de efeitos subletais na fertilidade e fecundidade dos adultos emergidos. Para ovos, os produtos fitossanitários foram classificados em função dos efeitos na redução

\footnotetext{
1 Discente, Programa de Pós-Graduação em Fitossanidade, Universidade Federal de Pelotas, UFPel, Pelotas, RS, Brasil. E-mail: frandearmas@gmail.com

2 Prof. Dr., Departamento de Fitossanidade, UFPel, Pelotas, RS, Brasil. E-mail: adgrutzm@ufpel.edu.br

3 Pesquisador, EMBRAPA Clima Temperado, Entomologia, Pelotas, RS, Brasil. E-mail: dori.edson-nava@embrapa.br

4 Discentes, Curso de Graduação em Agronomia, UFPel, Pelotas, RS, Brasil. E-mail: matheusrakes@hotmail.com; flavioamaralbueno@gmail.com

5 Prof. Dr., Curso de Agronomia, Centro de Ensino Superior Riograndense, CESURG, Sarandi, RS, Brasil. E-mail: rafaelpasini@, cesurg.com.br

* Author for correspondence
} 
da porcentagem de eclosão de larvas, e para pupas em função do efeito total, conforme a escala de toxicidade proposta pela International Organization for Biological and Integrated Control (IOBC). Todos os produtos fitossanitários (dosagem utilizada) foram inócuos (classe 1) aos ovos de C. externa, entretanto, abamectina (80) e cobre + cálcio (1\%) foram considerados levemente nocivos (classe 2 ) às pupas. Nos bioensaios com C. quadrifasciata, abamectina (80), deltametrina (40) e malationa (150) foram classificados como levemente nocivos (classe 2), enquanto fenitrotiona (100) apresentouse como moderadamente nocivo (classe 3 ) aos ovos do predador; para a fase de pupa, abamectina (80), fenitrotiona (100) e malationa (150) foram nocivos (classe 4). Os produtos Azadiractina (1\%), clorantraniliprole (14), deltametrina (40), cobre + cálcio $(25 \%+10 \%)$ e enxofre + cálcio $(3,5 \mathrm{Ba})$ são inócuos (classe 1) aos ovos e pupas de C. externa e C. quadrifasciata, e assim devem ser priorizados em pulverizações visando ao controle de pragas no MIP pessegueiro.

Palavras-chave: Crisopídeo. Joaninha. Fruticultura. Controle químico. Manejo integrado de pragas.

\section{Introduction}

Peach crop stands out in the temperate fruticulture. According to data from the Brazilian Institute of Geography and Statistics (IBGE, 2018), Brazil produced 222,613 tons of peach in the 2017 season. In this context, the state of Rio Grande do $\mathrm{Sul}$ is the main peach producer, standing out the municipalities of Pelotas and Canguçu (MADAIL, 2014), which account for more than $70 \%$ of the production destined to industry, a fact related to the number of agro-industries in the region (EHLERT, 2017).

The presence of insect pests in peach orchards may cause economic losses to producers. The fruit flies Anastrepha fraterculus (Wiedemann, 1930) and Ceratitis capitata (Wiedemann, 1824) (Diptera: Tephritidae), the oriental fruit moth Grapholita molesta (Busck, 1916) (Lepidoptera: Tortricidae), and the maize weevil Sitophilus zeamais (Motschulsky, 1885) (Coleoptera: Curculionidae) are the most important insect pests found in peach orchards (NAVA et al., 2014; NÖRNBERG et al., 2016). For satisfactory levels of production to be achieved, these pests are often controlled by applying chemicals (CHOUINARD et al., 2016). However, the indiscriminate use of these chemicals causes environmental imbalances mainly due to the mortality of biological control agents, such as natural enemies (DEGRANDE et al., 2002).

Among the natural enemies of peach pests is the green lacewing Chrysoperla externa (Hagen,
1861) (Neuroptera: Chrysopidae). This predatory species presents a high predation capacity during its larval stage, host diversity, high reproductive potential, ease of rearing in the laboratory, and tolerance to some pesticides, showing its potential for use in biological control programs of insect pests (CASTILHOS et al., 2014; PASINI et al., 2018). Other important predators in an orchard are from the Coccinellidae family, which stand out as being generalists from larval to adult stage, preying on insect pests such as aphids, mealybugs, psyllids, whiteflies, mites, eggs and immature beetles, and lepidopteran (GIORGI et al., 2009; LIXA et al., 2010). One of the species of this family that occurs in peach is the ladybug Coleomegilla quadrifasciata (Schöenherr, 1808) (Coleoptera: Coccinellidae), being considered an important biological control agent (ZAZYCKI, 2010).

The presence of predators in orchards is vital to the success of integrated pest management (IPM) in the peach crop and to preserve them in the agroecosystem, it is essential to use selective pesticides to populations of natural enemies (REDDY, 2016). It should also be taken into account that the egg and pupal stages are immobile and exposed to direct sprayings in orchards, which can cause lethal and sublethal effects on these developmental stages (RUGNO et al., 2015). Thus, studying pesticide selectivity on the egg and pupal stages is necessary since any impact in one of them can inhibit the development cycle and prevent the establishment of populations of $C$. externa and $C$. 
quadrifasciata in peach orchards (DEGRANDE et al., 2002).

In Brazil, there are few studies on pesticide selectivity in the peach crop using the egg and pupal stages of C. externa (CASTILHOS et al., 2014), and no study was found with $C$. quadrifasciata. Thus, due to the lack of data on pesticide selectivity, mainly using manipulated formulations, studies that address their lethal and sublethal effects on C. externa and C. quadrifasciata are required. Therefore, this study aimed to assess the selectivity of nine pesticides with commercial and manipulated formulations used in the peach crop on eggs and pupae of C. externa and C. quadrifasciata using methodology proposed by the International Organization for Biological and Integrated Control (IOBC).

\section{Material and Methods}

Rearing and maintenance of predators and alternative host

Eggs and pupae of $C$. externa and $C$. quadrifasciata used in the bioassays were obtained from a rearing maintained at the Laboratory of Integrated Pest Management (LabMIP) of the Federal University of Pelotas (UFPel) under controlled conditions (temperature of $25 \pm 1{ }^{\circ} \mathrm{C}$, relative humidity of $70 \pm 10 \%$, and photoperiod of 14 hours), according to methodology adapted from Silva et al. (2009) and Castilhos et al. (2014). The population of the alternative host Ephestia kuekniella (Zeller, 1879) was reared according to the methodology proposed by Parra (1997) and used to feed the larval stage of $C$. externa and the larval and adult stages of $C$. quadrifasciata. Adult individuals of C. externa fed the diet proposed by Vogt et al. (2000).

\section{Pesticides}

Nine pesticides (Table 1) recommended in the integrated peach production were used (BRASIL, 2003). Most of them are also in accordance with the doses proposed for the conventional cultivation (MAPA, 2018). The products were chosen because they are usually recommended not only for the peach cultivation but also in other temperate climate crops. Six commercial products were used and the used dose corresponded to the maximum recommended dose peach crop (MAPA, 2018). The three pesticides with manipulated formulation are listed in the Standards for the Organic Production of Plants and Animals (BRASIL, 1999), being used as recommended for the crop (Table 1).

Table 1. Pesticides used in the maximum recommendation for the peach crop in bioassays of eggs and pupae of Chrysoperla externa and Coleomegilla quadrifasciata.

\begin{tabular}{|c|c|c|c|c|}
\hline Technical name & Active ingredient (a.i.) & Chemical group & Maximum dose $^{1}$ & $\mathrm{C}^{2}$ \\
\hline \multicolumn{5}{|c|}{ Commercial formulation } \\
\hline Altacor & Chlorantraniliprole & Anthranilamide & 14 & 4.90 \\
\hline Decis $25 \mathrm{EC}$ & Deltamethrin & Pyrethroid & 40 & 1.00 \\
\hline Malathion $100 \mathrm{EC}$ & Malathion & Organophosphorus & 150 & 10.00 \\
\hline Neemax & Azadirachtin & Tetranortriterpenoid & $1 \%$ & 0.15 \\
\hline Sumithion 500 EC & Fenitrothion & Organophosphorus & 100 & 5.00 \\
\hline Vertimec 18 EC & Abamectin & Avermectin & 80 & 0.18 \\
\hline \multicolumn{5}{|c|}{ Manipulated formulation } \\
\hline Concentrated Bordatec & Copper + calcium & Inorganic & - & $25 \%+10 \%$ \\
\hline Bordeaux mixture & Copper + calcium & Inorganic & - & $1 \%$ \\
\hline Lime-sulfur solution & Sulfur + calcium & Inorganic & - & 3.5 $\mathrm{Ba}^{*}$ \\
\hline
\end{tabular}

${ }^{1} \mathrm{~mL}$ or g $100 \mathrm{~L}^{-1}$ of water; ${ }^{2}$ Concentration of a.i. in the solution, g $100 \mathrm{~L}^{-1}$ or $\%$; *Degree Baume (Ba). 
Pesticides with manipulated formulation consisted of concentrated Bordatec, Bordeaux mixture, and lime-sulfur solution. Concentrated Bordatec was prepared by dissolving the product in $500 \mathrm{~mL}$ of water and using a portable $\mathrm{pH}$ meter to check whether the $\mathrm{pH}$ was in the range of 7 to 9. Bordeaux mixture was prepared according to the recommendations of Fortes (2002) for temperate fruit trees by homogenizing $30 \mathrm{~g}$ of copper sulfate and $30 \mathrm{~g}$ of quicklime in $5 \mathrm{~L}$ of water and measuring the $\mathrm{pH}$ with a portable $\mathrm{pH}$ meter until it reached the range of 8 to 9. Lime-sulfur solution was prepared according to the methodology described by Venzon et al. (2016), in which the solution is composed of $100 \mathrm{~g}$ of sulfur, $50 \mathrm{~g}$ of quicklime and $5 \mathrm{~L}$ of water. These components were homogenized and heated to a reddish-gray color. Then, the density of this solution was measured with a Baume-type densimeter and the concentration was adjusted to 3.5 degrees Baume $(\mathrm{Ba})$.

\section{Bioassays}

The bioassays were conducted following the IOBC methodologies, as proposed by Medina et al. (2003). Product sprayings were carried out directly on eggs and pupae, both with approximately 24 hours of age. A manual sprayer with a $500 \mathrm{~mL}$ capacity (Guarany ${ }^{\circledR}$ Ultrajet, Itu, SP, Brazil) with a spray solution tank of $2 \pm 0.2 \mathrm{mg} \mathrm{cm}^{-2}$, measured through a precision scale, was used.

\section{Bioassay with eggs}

The experimental design was a completely randomized design with four replications of 24 eggs each, totaling 96 eggs per experimental unit. After spraying and drying of the applied pesticides on the eggs of C. externa and C. quadrifasciata, they were individualized in 96-well cell culture plates and maintained in an acclimatized room. At five days after individualization, egg viability and a consequent reduction in larval hatching (RLH) were assessed for each treatment.

\section{Bioassay with pupae}

The experimental design of the bioassay with pupae of $C$. externa and $C$. quadrifasciata was a completely randomized design with four replications of six pupae each, totaling 24 pupae per experimental unit. The pupae of predators were individualized in 24-well cell culture plates after spraying and subsequent drying of pesticides and maintained in a room under the same conditions of rearing. At seven days after application, viability and reduction of adult emergence (RAE) were assessed for each pesticide.

\section{Sublethal effects of sprayed adults in the pupal stage}

In addition to the lethal effects, the sublethal effects on fecundity and fertility of surviving adults from the applications in the pupal stage were also assessed. For this, five to seven couples of $C$. externa were separated into acrylic cages $(15.5 \mathrm{~cm}$ high $\times 18.5 \mathrm{~cm}$ in diameter) and five couples of $C$. quadrifasciata were separated into polyethylene containers $(9 \mathrm{~cm}$ high $\times 12 \mathrm{~cm}$ in diameter). Both predators were maintained in a room with climatic conditions and feeding equal to that of rearing. At seven days after the observation of the first oviposition, eggs from both species were collected daily for 10 consecutive days. The average number of eggs/female/day was determined from the daily count of eggs of C. externa and C. quadrifasciata. These eggs were then incubated in 96-well cell culture plates to determine the average percentage of larval hatching in each treatment.

\section{Selectivity classes}

The variables RLH and RAE were corrected as a function of the control treatment by the SchneiderOrelli equation (PÜNTENER, 1981). The total effect of each pesticide for pupae was calculated using the equation proposed by Vogt et al. (1992): E $=100 \%-(100 \%-\mathrm{RAE} \%) \times \mathrm{R} 1 \times \mathrm{R} 2$, where $\mathrm{E}$ is the total effect (\%), RAE\% is the reduction of adult 
emergence, $\mathrm{R} 1$ is the ratio between the average daily number of eggs laid per treated and untreated female, and R2 is the ratio between the average viability of eggs laid per treated and untreated female. The pesticides were classified according to their selectivity to eggs as a function of the reduction in the percentage of hatching and to the pupae as a function of the total effect, according to the toxicity classes proposed by IOBC (STERK et al., 1999): 1) harmless (<30\%); 2) slightly harmful (30-79\%); 3) moderately harmful (80-99\%); and 4) harmful (>99\%).

\section{Statistical analysis}

The data on egg and pupal viability, fecundity, and fertility were submitted to the exploratory analysis of normality of residuals by the Shapiro Wilk test and homoscedasticity by the Barlett test, with subsequent analysis of variance (ANOVA). The average viability of eggs and pupae of each treatment was compared with the control by the Dunnett's test $(\alpha=0.05)$, while the means of fecundity and fertility were compared by Tukey's test $(\alpha=0.05)$ when significant. The statistical analyses were performed using the statistical software Assistat version 7.7 (SILVA; AZEVEDO, 2016).

\section{Results and Discussion}

Egg viability of $C$. externa after pesticide applications ranged from 81.25 to $95.83 \%$. Products with the commercial formulation azadirachtin (1\%) and deltamethrin (40) provided egg viability of 81.25 and $83.33 \%$, respectively, differing significantly from the control (Figure 1). All the pesticides (commercial and manipulated formulations) were classified as harmless (class 1) to the egg stage of $C$. externa since RLH was lower than 30\% (Table 2).

Figure 1. Viability of eggs and pupae of Chrysoperla externa sprayed with pesticides used for peach crop.

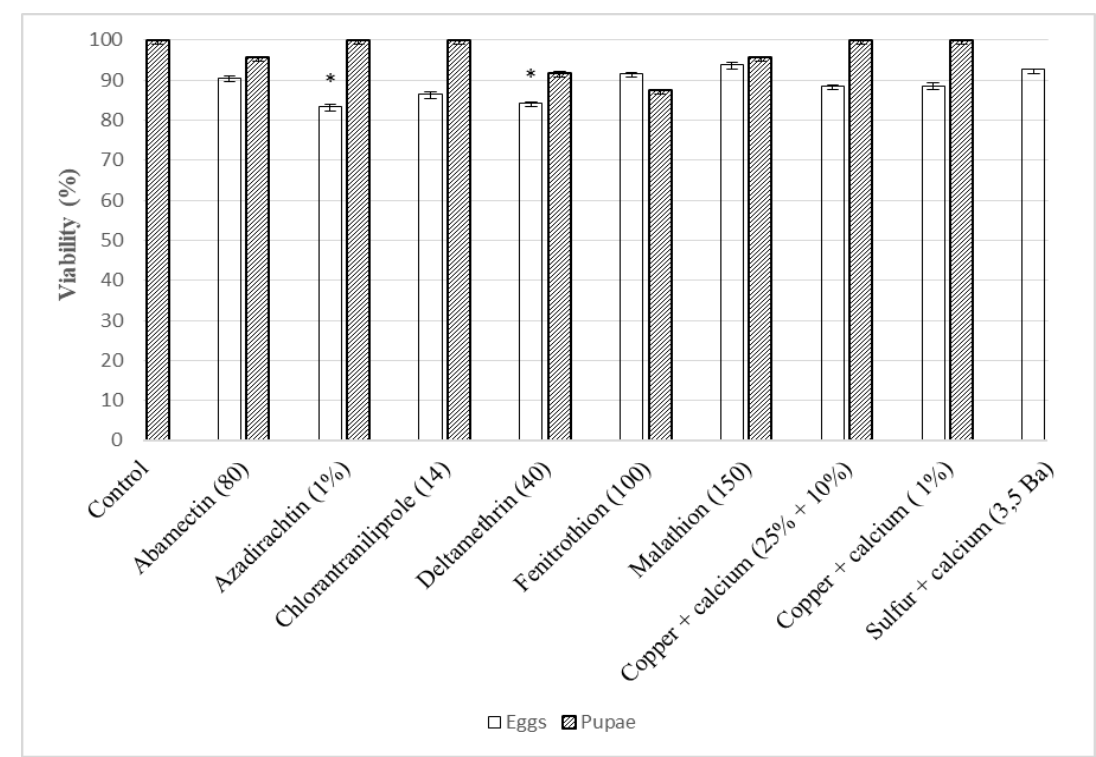

*Significant difference when compared to the control by the Dunnett's test at $5 \%$ probability. 
Table 2. Total effect and toxicity classification of pesticides used in the peach crop and applied to eggs and pupae of Chrysoperla externa.

\begin{tabular}{|c|c|c|c|c|c|c|c|c|}
\hline \multirow{2}{*}{ Treatment } & \multirow{2}{*}{$\mathbf{C P}^{1}$} & \multicolumn{2}{|c|}{ Eggs } & \multicolumn{5}{|c|}{ Pupae } \\
\hline & & $\mathbf{R L H}^{2}$ & $\mathrm{C}^{3}$ & $\mathbf{R A E}^{4}$ & Fecundity & Fertility & $E(\%)^{5}$ & $\mathrm{C}^{3}$ \\
\hline \multicolumn{9}{|c|}{ Commercial formulation } \\
\hline Control & - & - & - & 0.00 & $21.77 \pm 0.93^{\mathrm{ns}}$ & $95.88 \pm 0.22 \mathrm{a}$ & - & - \\
\hline Abamectin & 80 & 10.42 & 1 & 4.17 & $19.95 \pm 1.98$ & $73.75 \pm 1.06 \mathrm{~b}$ & 32.35 & 2 \\
\hline Azadirachtin & $1 \%$ & 18.75 & 1 & 0.00 & $22.43 \pm 0.89$ & $94.79 \pm 0.2 \mathrm{a}$ & 0.00 & 1 \\
\hline Chlorantraniliprole & 14 & 12.50 & 1 & 0.00 & $22.04 \pm 2.12$ & $85.41 \pm 0.25 \mathrm{ab}$ & 9.81 & 1 \\
\hline Deltamethrin & 40 & 16.67 & 1 & 8.33 & $20.20 \pm 0.29$ & $92.70 \pm 0.00 \mathrm{a}$ & 17.76 & 1 \\
\hline Fenitrothion & 100 & 8.33 & 1 & 12.50 & $19.55 \pm 0.45$ & $87.50 \pm 1.54 \mathrm{ab}$ & 28.29 & 1 \\
\hline Malathion & 150 & 4.17 & 1 & 12.50 & $21.04 \pm 2.17$ & $86.46 \pm 0.96 \mathrm{ab}$ & 23.74 & 1 \\
\hline \multicolumn{9}{|c|}{ Manipulated formulation } \\
\hline Copper + calcium & $25 \%+10 \%$ & 12.50 & 1 & 0.00 & $19.29 \pm 1.48$ & $93.75 \pm 0.25 \mathrm{a}$ & 13.36 & 1 \\
\hline Copper + calcium & $1 \%$ & 10.42 & 1 & 0.00 & $17.20 \pm 1.24$ & $82.30 \pm 0.65 \mathrm{ab}$ & 32.27 & 2 \\
\hline Sulfur + calcium & $3.5 \mathrm{Ba}^{*}$ & 8.33 & 1 & 4.17 & $19.47 \pm 1.25$ & $92.67 \pm 0.61 \mathrm{ab}$ & 16.01 & 1 \\
\hline
\end{tabular}

For the ladybug C. quadrifasciata, egg viability ranged from 11.45 to $84.37 \%$ so that the commercial formulation fenitrothion (100) caused the lowest index and the manipulated product sulfur + calcium $(3.5 \mathrm{Ba})$ led to the highest index. The commercial products abamectin (80), deltamethrin (40), fenitrothion (100), and malathion (150) provided significantly lower egg viability when compared to the control (Figure 2). Regarding selectivity classification of products tested on the ladybug eggs, azadirachtin (1\%), chlorantraniliprole (14), copper + calcium $(25 \%+10 \%)$, all products with manipulated formulation were considered harmless (class 1); abamectin (80), deltamethrin (14), and malathion (150) were slightly harmful (class 2); and fenitrothion (100) was classified as moderately harmful (class 3) since it caused an RLH of $83.33 \%$ (Table 3).

Most of the tested pesticides caused a low RAE of $C$. externa and pupal viability submitted to application ranged from 87.5 to $100 \%$ (Figure 1).
Regarding the pupal viability of C. quadrifasciata, the commercial products abamectin (80), fenitrothion (100), and malathion (150) caused an RAE of $100 \%$, significantly reducing predator viability (Figure 2 ). The products did not significantly reduce the fecundity of C. externa. However, when the fertility of these eggs was assessed, abamectin (80) provided significantly lower viability when compared to the control (Table 2).

Azadirachtin (1\%), chlorantraniliprole (14), deltamethrin (40), malathion (150), fenitrothion (100), copper + calcium $(25 \%+10 \%)$, and sulfur + calcium $(3.5 \mathrm{Ba})$ showed a total effect lower than $30 \%$ for C. externa, being considered harmless (class 1) (Table 2). Studies conducted by Zanuncio et al. (2016) showed that larvae of the predator Podisus nigrispinus (Dallas, 1851) (Heteroptera: Pentatomidae) exposed to concentrations of azadirachtin above $50 \%$ caused adult malformation and reproductive problems, but when the concentrations were higher than $25 \%$, 
they did not cause mortality or sublethal effects, thus evidencing the influence concentration on compound selectivity. These data are in accordance with the results obtained in our study, in which the used concentration was $1 \%$ and was also selective to C. externa.

Figure 2. Viability of eggs and pupae of Coleomegilla quadrifasciata sprayed with pesticides used for peach crop.

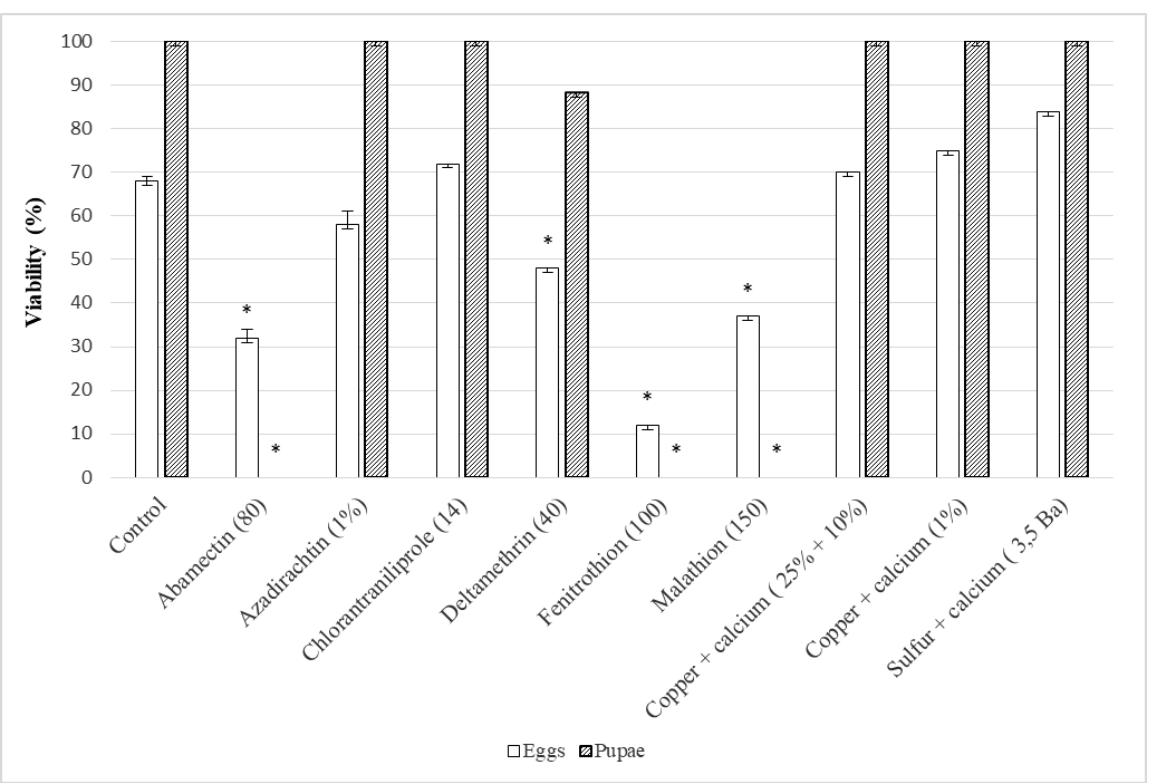

*Significant difference when compared to the control by the Dunnett's test at $5 \%$ probability.

Table 3. Total effect and toxicity classification of pesticides used in the peach crop and applied to eggs and pupae of Coleomegilla quadrifasciata.

\begin{tabular}{|c|c|c|c|c|c|c|c|c|}
\hline \multirow{2}{*}{ Treatment } & \multirow{2}{*}{$\mathbf{C P}^{1}$} & \multicolumn{2}{|c|}{ Eggs } & \multicolumn{5}{|c|}{ Pupae } \\
\hline & & $\mathbf{R L H}^{2}$ & $\mathbf{C}^{3}$ & $\mathbf{R A E}^{4}$ & Fecundity & Fertility & $E(\%)^{5}$ & $\mathbf{C}^{3}$ \\
\hline \multicolumn{9}{|c|}{ Commercial formulation } \\
\hline Control & - & - & - & 0.00 & $24.41 \pm 3.22^{\mathrm{ns}}$ & $88.33 \pm .82^{\mathrm{ns}}$ & - & - \\
\hline Abamectin & 80 & 54.55 & 2 & 100.00 & - & - & 100.00 & 4 \\
\hline Azadirachtin & $1 \%$ & 15.55 & 1 & 0.00 & $26.16 \pm 2.12$ & $79.17 \pm 1.58$ & 1.81 & 1 \\
\hline Chlorantraniliprole & 14 & 0.00 & 1 & 0.00 & $28.24 \pm 2.94$ & $71.87 \pm 1.49$ & 5.86 & 1 \\
\hline Deltamethrin & 40 & 43.94 & 2 & 8.33 & $27.27 \pm 2.69$ & $70.00 \pm 1.43$ & 26.97 & 1 \\
\hline Fenitrothion & 100 & 83.33 & 3 & 100.00 & - & - & 100.00 & 4 \\
\hline Malathion & 150 & 45.45 & 2 & 100.00 & - & - & 100.00 & 4 \\
\hline \multicolumn{9}{|c|}{ Manipulated formulation } \\
\hline Copper + calcium & $25 \%+10 \%$ & 0.00 & 1 & 0.00 & $28.60 \pm 3.18$ & $69.79 \pm 3.18$ & 0.64 & 1 \\
\hline Copper + calcium & $1 \%$ & 0.00 & 1 & 0.00 & $28.96 \pm 1.19$ & $75.00 \pm 0.71$ & 0.73 & 1 \\
\hline Sulfur + calcium & $3.5 \mathrm{Ba}^{*}$ & 0.00 & 1 & 0.00 & $26.17 \pm 2.32$ & $81.00 \pm 2.32$ & 1.69 & 1 \\
\hline
\end{tabular}

${ }^{1} \mathrm{CP}=$ dose of commercial product ( $\mathrm{g}$ or $\mathrm{mL} 100 \mathrm{~L}^{-1}$ ) or percentage of concentration of the active ingredient in the solution; ${ }^{2} \mathrm{RLH}=$ reduction in larval hatching corrected by Schneider-Orelli $(\%) ;{ }^{3} \mathrm{C}=\mathrm{IOBC}$ classes: $1=$ harmless $(<30 \%), 2=$ slightly harmful $(30$ $79 \%), 3=$ moderately harmful (80-99\%), and $4=$ harmful $(>99 \%) ;{ }^{4} \mathrm{RAE}=$ reduction of adult emergence corrected by SchneiderOrelli (\%); ${ }^{5} \mathrm{E}=$ total effect $(\%) ;{ }^{*}$ Degree Baume; ${ }^{\mathrm{n}}=$ not significant at 5\% probability (ANOVA). Means followed by the same letter in the column do not differ significantly from each other by the Tukey's test at 5\% probability. 
The insecticide abamectin (80) presented a total effect of $32.35 \%$, being considered slightly harmful (class 2) to C. externa, mainly due to a reduction in the fertility of adults emerged from treated pupae (Table 2). Similar results were found in the coffee crop, in which the same active ingredient was considered slightly harmful to eggs of C. externa, with egg viability of 65 and $57 \%$ for concentrations of 0.0067 and $0.0225 \mathrm{~g}$ a.i. $\mathrm{L}^{-1}$, respectively (VILELA et al., 2010). Abamectin acts as a GABA (gamma-aminobutyric acid) agonist, with the ability to mimic the molecules of this neurotransmitter in the nervous system of insects. Thus, it binds to receptors and stimulates the flow of chlorine ions into nerve cells and neuromuscular junctions, leading to the blockade of nerve stimulus transmission and hence the death of these arthropods (AZOD et al., 2016). Studies with predatory mites of the Phytoseiidae family (HAN et al., 2010) and the ladybird Menochilus sexmaculatus (Fabricius, 1781) (Coleoptera: Coccinellidae) (AZOD et al., 2016) reported that despite the immediate mortality of natural enemies when exposed to high doses of this product, it does not cause sublethal damage to surviving populations or exposed to a lower dose, thus being a viable alternative to IPM programs.

Both fecundity and fertility of adults of $C$. quadrifasciata that survived the applications on pupae showed no significant reduction. Azadirachtin (1\%), chlorantraniliprole (14), deltamethrin (40), copper + calcium $(25 \%+10 \%)$, copper + calcium $(1 \%)$, and sulfur + calcium $(3.5 \mathrm{Ba})$ were classified as harmless (class 1) to pupae of C. quadrifasciata, with a total effect lower than $30 \%$. In contrast, abamectin (80), fenitrothion (100), and malathion (150) were considered harmful (class 4), as they caused an RAE of $100 \%$ (Table 3 ).

The fact that most of the products did not affect the fecundity and fertility of C. externa (Table 2) and $C$. quadrifasciata (Table 3 ) is very important for the viability of the biological control exerted by these predators in the peach crop since populations of natural enemies may succumb not only to mortality caused by pesticides but also to sublethal effects that affect the physiology or behavior of the insects (DESNEUX et al., 2007).

The active ingredient chlorantraniliprole is recognized by its selectivity to mammals and natural enemies, acting on the muscular system of insects by means of the activation of ryanodine receptors and release of calcium in the sarcoplasmic reticulum of muscular cells, thus regulating the intramuscular calcium balance (SATTELLE et al., 2008). This commercial product, even causing a reduction of $12.50 \%$ in RLH of $C$. externa, was considered harmless (class 1) (Table 2). In $C$. quadrifasciata, chlorantraniliprole did not alter the percentage of larval hatching (Table 3 ). This result was also observed in the pupal stage, in which a total effect of 9.81 and $5.86 \%$ was observed in $C$. externa and C. quadrifasciata, respectively, being considered selective to both (Tables 2 and 3 ).

Deltamethrin (40) did not present toxicity to $C$. externa in any of the stages in which it was applied (Table 2), being also classified as harmless (class 1) to the pupae of $C$. quadrifasciata, presenting $26.97 \%$ of total effect (Table 3 ). Similar results were obtained by Godoy et al. (2004), who classified this pyrethroid as selective to eggs of C. externa in citrus. A hypothesis for the selectivity of predators to pyrethroids is the metabolization of product molecules through the metabolic detoxification of microsomal oxidases and esterases, which is one of the factors favoring insect pest resistance to this insecticide group (LILLY et al., 2016), being also a route of metabolization in natural enemies.

However, in the egg stage of C. quadrifasciata, deltamethrin (40) was classified as slightly harmful (class 2) (Table 3). Fogel et al. (2016) used cypermethrin at a dose of $25 \mathrm{mg}$ a.i. $\mathrm{L}^{-1}$ in pupae of E. connexa pupae and observed a $41 \%$ reduction in pupal survival, which is similar to the result found in our study for deltamethrin (RLH of 43.94\%) (Table 3 ). Products of the chemical group of pyrethroids 
act in the opening of sodium channels, influencing the ionic permeability of cellular membranes. The selectivity observed for deltamethrin may be related to the low penetration rate due to the lipophilicity of the compound and thickness and composition of eggs and pupae (DONG et al., 2014).

The organophosphorus fenitrothion (100) and malathion(150) were harmless (class 1) to both stages of development of C. externa (Table 2). Castilhos et al. (2014) found similar results when using fenthion (0.050) and phosmet (0.100), belonging to the same toxicological class, which were harmless to eggs and pupae of $C$. externa. These insecticides act by inhibiting the enzyme acetylcholinesterase in the nerve synapses, causing the continuous passage of impulses and causing insect death. However, a lower sensitivity of the enzyme acetylcholinesterase on predators or even changes in specific genes may explain the selectivity of these products (BACCI et al., 2007) as they are known to be harmful to natural enemies and pollinators (BOTTON et al., 2011).

Fenitrothion was moderately harmful (class 3) for C. quadrifasciata because it reduced larval hatching by $83.33 \%$. Malathion reduced to $45.45 \%$ this parameter, being considered as moderately harmful (class 2) (Table 3). Torres et al. (2013) obtained similar results when using chlorpyrifos (0.60) on pupae of $C$. externa in the coffee crop, leading to an RAE of $62 \%$, which is attributed to the residual period of organophosphorus. Adult death occurs during the emergence because of contamination through contact of the newly emerged insect or insect body parts during ecdysis with the integument of sprayed pupae.

The insecticide/acaricide abamectin (80) was selective to eggs of $C$. externa, which was also verified by Carvalho et al. (2011) in the apple tree. For the Coccinellidae C. quadrifasciata, abamectin caused a reduction of $54.55 \%$ in the egg stage, being classified as slightly harmful (class 2), in addition to causing mortality of $100 \%$ of pupae (Table 3). According to Galvan et al. (2002), abamectin was moderately harmful to Brachygastra lecheguana (Latreille, 1824) and Protopolybia exigua (Saussure, 1906) and toxic to Protonectarina sylveirae (Saussure, 1954) (Hymenoptera: Vespidae) at concentrations corresponding to $50 \%$ (underdose) and 100\% (dose) in the citrus crop. These effects were due to the high molecular weight and complex structure of the insecticide/ acaricide molecule, which decreases the cuticle penetration rate and makes it more susceptible to the action of detoxifying enzymes, respectively (HORNSBY et al., 1996).

The commercial formulations azadirachtin (1\%) and chlorantraniliprole (14) and the manipulated formulations copper + calcium $(1 \%)$ and sulfur + calcium $(3.5 \mathrm{Ba})$ were not toxic to the egg and pupal stages of $C$. externa and $C$. quadrifasciata, being considered harmless (class 1) (Tables 2 and 3 ). These results are similar to those obtained with pupae of the parasitoid Telenomus remus (Nixon, 1937) (Hymenoptera: Platygastridae) when using commercial mixtures such as Borda-Ferti pH 7 (7\% copper $+3.3 \%$ calcium) and Lime-sulfur mixture $(20 \%$ sulfur $+10 \%$ quicklime $)$, which were classified as slightly harmful (class 2) (SILVA et al., 2016). Similarly, selective tests carried out by Silva and Bueno (2014), who used the commercial mixture Borda-Ferti pH 7 ( $7 \%$ copper $+3.3 \%$ calcium) in the pupal stage of Telenomus podisi (Ashmead, 1893) (Hymenoptera: Platygastridae), showed no RAE and was considered as harmless (class 1). Lime-sulfur mixture (20\% sulfur $+10 \%$ quicklime) was tested in that experiment and showed to be harmless in all assessments, not causing a reduction in the adult emergence rate or changing the parasitism rate.

The product sulfur + calcium $(3.5 \mathrm{Ba})$ was harmless (class 1) to the egg and pupal stages of both predators (Tables 2 and 3). Studies using the acaricide Kumulus, which contains sulfur in its formulation, showed that the product was selective to eggs of C. externa in coffee (SILVA et al., 2006) and to the egg and pupal stages of this predator in 
peach orchards (CASTILHOS et al., 2014). For predators of the Arachnida class, sulfur + calcium $(3.5 \mathrm{Ba})$ was less selective, causing a reduction in the populations of the predatory mite Iphiseiodes zuluagai and Euseius spp. in citrus (ANDRADE et al., 2010).

In this sense, C. quadrifasciata was more affected, mainly in the egg stage. The commercial formulations abamectin (80), deltamethrin (40), fenitrothion (100), and malathion (150) showed higher toxicity, which was repeated in the pupal stage with abamectin (80), fenitrothion (100), and malathion (150) (Table 3). It is important to emphasize that in addition to the formulation of insecticides, morphological issues related to each species may explain the permeability of some insecticides, which could serve as channels for the penetration of insecticides, which may have occurred with the products abamectin (80), deltamethrin (40), fenitrothion (100), and malathion (150). However, the data found in the literature on these peculiarities are still scarce (RIMOLDI et al., 2017). In our study, the assessment of insecticide toxicity on eggs was restricted to the verification of a reduction in the percentage of larval hatching. However, possible sublethal effects such as changes in embryo duration and harmful effects on larvae and adults from treated eggs may have influenced the impact of a certain insecticide on the egg stage of C. externa and C. quadrifasciata in the peach crop.

Egg chorion constitutes a chemical and physical barrier to insecticides, favoring the development of the embryo and preventing the entry of hydrophilic substances and the exit of water (NATION, 2008; RIMOLDI et al., 2017). In addition, according to Cosme et al. (2009), the silk cocoon that protects the pupae of $C$. externa has holes that allow breathing and where pesticides can possibly reach the insect. However, as can be observed, the insecticides probably were not able to penetrate through these holes, demonstrating that the pupa acts as a physical barrier, avoiding insect contamination and, consequently, not reducing the emergence of adults of C. externa (Table 2). Another issue related to the penetration of insecticides into the outer layer of eggs and pupae is related to the molecular weight of these products (MOSCARDINI et al., 2013). Thus, part of the insecticides, including the neurotoxic ones, were not toxic because their formulations were not able to penetrate the egg chorion.

Most of the tested pesticides were harmless to the egg and pupa stages of C. externa. However, many pesticides were toxic to the egg and pupal stages of the ladybug C. quadrifasciata. Therefore, caution is needed in the use of these products in the peach IPM since they may adversely affect the natural enemies present in orchards, especially the commercial formulations abamectin (80), fenitrothion (100), and malathion (150), which affected both stages of the predator development. Thus, these products should be avoided, preferring the adoption of selective products to $C$. externa and C. quadrifasciata in order to favor the maintenance of the natural biological control exerted by both predators in peach orchards.

This study assessed the selectivity, under laboratory conditions, of several pesticides using a standardized methodology of IOBC. For those products that presented classes 3 (moderately harmful) and 4 (harmful), new studies are needed under semi-field and field conditions (HASSAN, 1988) to determine its real impact on the predators C. externa and C. quadrifasciata. The results of this study have great importance for peach cultivation since selective pesticides should have their use prioritized in IPM, thus contributing to the preservation of the predators $C$. externa and $C$. quadrifasciata in orchards.

Therefore, abamectin (80), azadirachtin (1\%), chlorantraniliprole (14), deltamethrin (40), fenitrothion (100), malathion (150), copper + calcium $(25 \%+10 \%)$, copper + calcium $(1 \%)$, and sulfur + calcium $(3.5 \mathrm{Ba})$ are harmless (class 1$)$ to eggs of C. externa. Abamectin (80) and copper + 
calcium (1\%) are slightly harmful (class 2$)$ to pupae of $C$. externa. The products azadirachtin $(1 \%)$, chlorantraniliprole $(14)$, copper + calcium $(25 \%+$ $10 \%)$, copper + calcium $(1 \%)$, and sulfur + calcium (3.5 $\mathrm{Ba})$ are harmless (class 1$)$ to the egg stage of C. quadrifasciata. Abamectin (80), deltamethrin (40), and malathion (150) are slightly harmful (class 2), while fenitrothion (100) is moderately harmful (class 3) to the egg stage. Abamectin (80), fenitrothion (100), and malathion (150) are harmful (class 4) to the pupae of this natural enemy.

\section{Acknowledgments}

To the Coordination for the Improvement of Higher Education Personnel (CAPES) for granting the master's scholarship to the first author and to the National Council for Scientific and Technological Development (CNPq) for the financial support.

\section{References}

ANDRADE, D. J. D.; OLIVEIRA, C. A. L. D.; PATTARO, F. C.; SIQUEIRA, D. S. Acaricidas utilizados na citricultura convencional e orgânica: manejo da leprose e populações de ácaros fitoseídeos. Revista Brasileira de Fruticultura, Jaboticabal, v. 32, n. 4, p. 1028-1037, 2010. DOI: $10.1590 / \mathrm{S} 0100-29452011005000013$

AZOD, F.; SHAHIDI-NOGHABI, S.; MAHDIAN, K.; SMAGGHE, G. Lethal and sublethal effects of spirotetramat and abamectin on predatory beetles (Menochilus sexmaculatus) via prey (Agonoscena pistaciae) exposure, important for integrated pest management in pistachio orchards. Belgian Journal of Zoology, Brussels, v. 146, n. 2, p. 113-122, 2016.

BACCI, L.; CRESPO, A. L.; GALVAN, T. L.; PEREIRA, E. J.; PICANÇO, M. C.; SILVA, G. A.; CHEDIAK, M. Toxicity of insecticides to the sweetpotato whitefly (Hemiptera: Aleyrodidae) and its natural enemies. Pest Management Science, Medford, v. 63, n. 7, p. 699-706, 2007. DOI: $10.1002 / p s .1393$

BOTTON, M.; NAVA, D. E.; ARIOLI, C. J.; GRÜTZMACHER, A. D.; GARCIA, M. S. Bioecologia, monitoramento e controle da mariposa-oriental na cultura do pessegueiro no Rio Grande do Sul. Bento Gonçalves: EMBRAPA Uva e Vinho, 2011. 11 p. (Circular técnico, 86).
BRASIL. Instrução Normativa $\mathrm{n}^{\circ} 7$ de 17/05/1999. Diário Oficial [da] União, Brasília, 1999. Disponível em: http://ibd.com.br/Media/arquivo_digital/c40fe6c451f3-414a-9936-49ea 814fd64c.pdf. Acesso em: 22 abr. 2018.

BRASIL. Normas técnicas específicas para a produção integrada de pêssego. Grade de agroquímicos. Instrução Normativa/ SARC n $016-1^{\circ}$ de dezembro de 2003. Diário Oficial [da] União, Brasília, 2003. Disponível em: http://www.inmetro.gov.br/credenciamento/pessego/ GradeAgroquimicos.pdf. Acesso em: 2 jan. 2018.

CARVALHO, A. G.; CARVALHO, C. F.; FERREIRA, M. N. Toxicidade de acaricidas a ovos e adultos de Ceraeochrysa cubana (Hagen, 1861) (Neuroptera: Chrysopidae). Ciência e Agrotecnologia, Lavras, v. 35 , n. 1 , p. $165-171,2011$. DOI: $10.1590 / \mathrm{S} 1413-$ 70542011000100021

CASTILHOS, R. V.; GRÜTZMACHER, A. D.; SIQUEIRA, P. R. B.; MORAES, I. L.; GAUER, C. J. Seletividade de agrotóxicos utilizados em pessegueiro sobre ovos e pupas do predador Chrysoperla externa. Ciência Rural, Santa Maria, v. 44, n. 11, p. 1921-1928, 2014. DOI: $10.1590 / 0103-8478$ cr20140248

CHOUINARD, G.; FIRLEJ, A.; CORMIER, D. Going beyond sprays and killing agents: exclusion, sterilization and disruption for insect pest control in pome and stone fruit orchards. Scientia Horticulturae, Amsterdam, v. 208, n. 1, p. 13-27, 2016. DOI: 10.1016/j.scienta.2016.03.014

COSME, L. V.; CARVAlHO, G. A.; MOURA, A. P.; PARREIRA, D. S. Toxicidade de óleo de nim para pupas e adultos de Chrysoperla externa (Hagen) (Neuroptera: Chrysopidae). Arquivos do Instituto Biológico, São Paulo, v. 76, n. 2, p. 233-238, 2009.

DEGRANDE, E. P.; REIS, R. P.; CARVALHO, A. G.; BELARMINO, L. C. Metodologia para avaliar o impacto de pesticidas sobre inimigos naturais. In: PARRA, J. R. P.; BOTELHO, P. S. M.; FERREIRA, B. S. C.; BENTO, J. M. S. (Ed.). Controle biológico no Brasil: parasitoides e predadores. São Paulo: Manole, 2002. cap. 5, p. 427447.

DESNEUX, N.; DECOURTYE, A.; DELPUECH, J. M. Sublethal effects of pesticides on beneficial arthropods. Annual Review of Entomology, Palo Alto, v. 52, n. 1, p. 81-106, 2007.

DONG, K.; DU, Y.; RINKEVICH, F.; NOMURA, Y.; XU, P.; WANG, L.; SILVER, K.; ZHOROV, B. S. Molecular biology of insect sodium channels and pyrethroid resistance. Insect Biochemistry and Molecular Biology, Riverside, v. 50, n. 1, p. 1-17, 2014. DOI: $10.1016 /$ j. ibmb.2014.03.012 
EHLERT, E. Dados da cadeira produtiva do pêssego. 2017. Disponível em: http://www.azonasul.org. br/ Noticia/1520/DADOS-CADEIA-PRODUTIVADOPESSEGO. Acesso em: 1 fev. 2018.

FOGEL, M. N.; SCHNEIDER, M. I.; RIMOLDI, F.; LADUX, L. S.; DESNEUX, N.; RONCO, A. E. Toxicity assessment of four insecticides with different modes of action on pupae and adults of Eriopis connexa (Coleoptera: Coccinellidae), a relevant predator of the Neotropical Region. Environmental Science and Pollution Research, Bordeaux, v. 23, n. 15, p. 1491814926, 2016.

FORTES, J. F. Tratamento de inverno para o cultivo do pessegueiro. Pelotas: EMBRAPA Clima Temperado, 2002. 2 p. (Comunicado técnico, 70).

GALVAN, T. L.; PICANÇO, M. C.; BACCI, L.; PEREIRA, E. J. G.; CRESPO, A. L. B. Seletividade de oito inseticidas a predadores de lagartas em citros. Pesquisa Agropecuária Brasileira, Brasília, v. 37, n. 2, p. 117-122, 2002.

GIORGI, J. A.; VANDENBERG, N. J.; MCHUGH, J. V.; FORRESTER, J. A.; SLIPINSKI, S. A.; MILLER, K. B.; SHAPIRO, L. R.; WHITING, M. F. The evolution of food preferences in Coccinellidae. Biological Control, San Diego, v. 51, n. 2, p. 215-231, 2009. DOI: 10.1016/j. biocontrol.2009.05.019

GODOY, M. S.; CARVAlHO, G. A.; MORAES, J. C.; GOUSSAIN, M. M.; MORAIS, A. A.; COSME, L. V. Seletividade de inseticidas utilizados na cultura dos citros para ovos e larvas de Chrysoperla externa (Hagen) (Neuroptera: Chrysopidae). Neotropical Entomology, Londrina, v. 33, n. 5, p. 639-646, 2004.

HAN, J.; CHOI, B. R.; LEE, S. G.; KIM, S. I.; AHN, Y. J. Toxicity of plant essential oils to acaricide-susceptible and-resistant Tetranychus urticae (Acari: Tetranychidae) and Neoseiulus californicus (Acari: Phytoseiidae). Journal of Economic Entomology, Annapolis, v. 103, n. 4, p. 1293-1298, 2010. DOI: 10.1603/EC09222

HASSAN, S. A. Guideline for testing the side effect of pesticides on the egg parasite Trichogramma cacoeciae. Bulletin SROP, Montfavet, n. 11, n. 1, p. 3-18, 1988.

HORNSBY, A. G.; WAUCHOPE, R.; HERNER, A. E. Pesticide properties in the environment. New York: Springer, 1996. $227 \mathrm{p}$.

INSTITUTO BRASILEIRO DE GEOGRAFIA E ESTATÍSTICA - IBGE. Censo Agropecuário, 2017. 2018. Disponível em: https://www.ibge.gov.br/estatisticasnovoportal/economicas/agricultura-e-pecuaria/218142017-censo-agropecuario.html? $=\& \mathrm{t}=$ resultados. Acesso em: 1 set. 2018.
LILLY, D. G.; DANG, K.; WEBB, C. E.; DOGGETT, S. L. Evidence for metabolic pyrethroid resistance in the common bed bug (Hemiptera: Cimicidae). Journal of Economic Entomology, Annapolis, v. 109, n. 3, p. 13641368, 2016. DOI: 10.1093/jee/tow041

LIXA, A. T.; CAMPOS, J. M.; RESENDE, A. L. S.; SILVA, J. C.; ALMEIDA, M. M. T. B.; AGUIARMENEZES, E. L. Diversidade de Coccinellidae (Coleoptera) em plantas aromáticas (Apiaceae) como sítios de sobrevivência e reprodução em sistema agroecológico. Neotropical Entomology, Londrina, v. 39, n. 3, p. 354-359, 2010.

MADAIL, J. O cultivo do pessegueiro no Rio Grande do Sul. In: RASEIRA, M. C. B.; PEREIRA, J. F. M.; CARVAlHO, F. L. C. (Ed.). Pessegueiro. Brasília: EMBRAPA, 2014. cap. 22, p. 615-624.

MEDINA, P.; BUDIA, F.; DEL ESTAL, P.; ADÁN, A.; VIÑUELA, E. Side effects of six insecticides on different developmental stages of Chrysoperla carnea (Neuroptera: Chrysopidae). IOBC/WPRS Bulletin, Gent, v. 26, n. 5, p. 33-40, 2003.

MINISTÉRIO DA AGRICULTURA, PECUÁRIA E ABASTECIMENTO - MAPA. AGROFIT. Sistema de inseticidas fitossanitários. 2018. Disponível em: http://agrofit.agricultura.gov.br/agrofit_cons/principal_ agrofit_cons. Acesso em: 15 fev. 2018.

MOSCARDINI, V. F.; GONTIJO, P. C.; CARVALHO, G. A.; OLIVEIRA, R. L.; MAIA, J. B.; SILVA, F. F. Toxicity and sublethal effects of seven insecticides to eggs of the flower bug Orius insidiosus (Say) (Hemiptera: Anthocoridae). Chemosphere, Amsterdam, v. 92, n. 5, p. 490-496, 2013. DOI: 10.1016/j. chemosphere.2013.01.111

NATION, J. L. Reproduction. In: NATION, J. L. (Ed.). Insect physiology and biochemistry. Flórida: CRC Press, 2008. p. 561-591.

NAVA, D. E.; BOTTON, M.; ARIOLI, C. J.; GARCIA, M. S.; GRÜTZMACHER, A. D. Insetos e ácaros praga. In: RASEIRA, M. C. B.; PEREIRA, J. F. M.; CARVALHO, F. L. C. (Ed.). Pessegueiro. Brasília: EMBRAPA, 2014. cap. 16, p. 433-486.

NÖRNBERG, S. D.; GRÜTZMACHER, A. D.; NAVA, D. E.; VALGAS, R. A.; OZELAME, A. L. Residual effects of pesticides in peach orchards on the maize weevil Sitophilus zeamais (Coleoptera: Curculionidae). Revista Brasileira de Fruticultura, Jaboticabal, v. 38, n. 3, p. 1-8, 2016. DOI: 10.1590/0100-29452016017

PARRA, J. R. P. Técnicas de criação de Anagasta kuehniella, hospedeiro alternativo para produção de Trichogramma. In: PARRA, J. R. P.; ZUCCHI, R. A. 
(Ed.). Trichogramma e o controle biológico aplicado. Piracicaba: FEALQ, 1997. p. 121-150.

PASINI, R. A.; GRÜTZMACHER, A. D.; PAZINI, J. B.; ARMAS, F. S. de; BUENO, F. A.; PIRES, S. N. Side effects of inseticides used in wheat crop on eggs and pupae of Chrysoperla externa and Eriopis connexa. Phytoparasitica, Dordrecht, v. 46, n. 1, p. 115-125, 2018. DOI: $10.1007 / \mathrm{s} 12600-018-0639-9$

PÜNTENER, W. Manual for field trials in plant protection. $2^{\text {th }}$ ed. Basle: Ciba-Geigy, 1981. 205 p.

REDDY, P. P. Selective pesticides in IPM. In: REDDY, P. P. (Ed.). Sustainable crop protection under protected cultivation. Singapore: Springer, 2016. p. 121-131.

RIMOLDI, A. F.; FOGEL, B. M. N.; RONCO, A. E.; SCHNEIDER, M. I. Comparative susceptibility of two Neotropical predators, Eriopis connexa and Chrysoperla externa, to acetamiprid and pyriproxyfen: short and long-term effects after egg exposure. Environmental Pollution, Rensselaer, v. 231, n. 1, p. 1042-1050, 2017. DOI: $10.1016 /$ j.envpol.2017.08.097

RUGNO, G. R.; ZANARDI, O. Z.; YAMAMOTO, P. T. Are the pupae and eggs of the lacewing Ceraeochrysa cubana (Neuroptera: Chrysopidae) tolerant to insecticides? Journal of Economic Entomology, Annapolis, v. 108, n. 6, p. 2630-2639, 2015. DOI: $10.1093 /$ jee/tov263

SATTELlE, D.; CORDOVA, D.; CHEEK, T. Insect ryanodine receptors: molecular targets for novel pest control chemicals. Invertebrate Neuroscience, Southampton, v. 8 , n. 3, p. 107-119, 2008. DOI: $10.1007 /$ s10158-008-0076-4

SILVA, D. M.; BUENO, A. F. Toxicity of organic supplies for the egg parasitoid Telenomus podisi. Ciência Rural, Santa Maria, v. 44, n. 1, p. 11-17, 2014. DOI: 10.1590/ S0103-84782014000100003

SILVA, D. M.; BUENO, A. F.; ANDRADE, K.; STECCA, C. S.; NEVES, P. M. O. J.; MOSCARDI, F. Selectivity of organic compounds to the egg parasitoid Telenomus remus Nixon (Hymenoptera: Plastygastridae). Semina: Ciências Agrárias, Londrina, v. 37, n. 1, p. 55-66, 2016. DOI: 10.5433/1679-0359.2016v37n1p55

SILVA, F. A. S.; AZEVEDO, C. A. V. The assistat software version 7.7 and its use in the analysis of experimental data. African Journal of Agricultural Research, Nairobi, v. 11, n. 39, p. 3733-3740, 2016. DOI: 10.5897/AJAR2016.11522

SILVA, R. A.; REIS, P. R.; CARVALHO, C. F.; SOUZA, B. Capacidade predatória de Chrysoperla externa (Hagen, 1861) (Neuroptera:Chrysopidae) sobre Brevipalpus phoenicis (Geijskes, 1939) (Acari: Tenuipalpidae).
Coffee Science, Lavras, v. 1, n. 1, p. 50-54, 2006.

SILVA, R. B.; ZANUNCIO, J. C.; SERRÃO, J. E.; LIMA, E. R.; FIGUEIREDO, M. L. C.; CRUZ, I. Suitability of different artificial diets for development and survival of stages of the predaceous ladybird beetle Eriopis connexa. Phytoparasitica, Bet Dagan, v. 37, n. 2, p. 115-123, 2009. DOI 10.1007/s12600-008-0015-2

STERK, G.; HASSAN, S. A.; BAILLOD, M.; BAKKER, F.; BIGLER, F.; BLUME, L S.; BOGENSCHUTZ, H.; BOLLER, E.; BROMAND, B.; BRUN, J.; CALIS, J. N. M.; COREMANS-PELSENEER, J.; DUSO, C.; GARRIDO, A.; GROVE, A.; HEIMBACH, U.; HOKKANEN, H.; JACAS, J.; LEWIS, G.; MORETH, L.; POLGAR, L.; ROVERSTI, L.; SAMSOE-PETERSON, L.; SAUPHANOR, B.; SCHAUB, L.; STAUBLI, A.; TUSET, J. J.; VAINIO, A.; VAN DE VEIRE, M.; VIGGIANI, G.; VINUELA, E.; VOGT, H. Results of the seventh joint pesticide testing programme carried out by the IOBC/WPRS-working group pesticides and beneficial organisms. Biocontrol, Dordrecht, v. 44, n. 1, p. 99-117, 1999. DOI: 10.1023/A:1009959009802

TORRES, A. F.; CARVALHO, G. A.; SANTA-CECÍLIA, L. V. C.; MOSCARDINI, V. F. Selectivity of seven insecticides against pupae and adults of Chrysoperla externa (Neuroptera: Chrysopidae). Revista Colombiana de Entomología, Bogotá, v. 39, n. 1, p. 34-39, 2013.

VENZON, M.; DIEZ-RODRÍGUEZ, G. I.; FERRAZ, C. S.; LEMOS, F.; NAVA, D. E.; PALLINI, A. Manejo agroecológico das pragas das fruteiras. Informe Agropecuário, Belo Horizonte, v. 37, n. 293, p. 94- 103, 2016.

VILELA, M.; CARVALHO, G. A.; CARVALHO, C. F.; BOAS, M. A. V. Effects of acaricides used in coffee crops on the eggs and subsequent stages of green lacewing. Coffee Science, Lavras, v. 5, n. 1, p. 10-16, 2010.

VOGT, H.; BIGLER, F.; BROWN, K.; CANDOLFI, M. P.; KEMMETER, F.; KÜHNER, C.; MOLL, M.; TRAVIS, A.; UFER, A.; VIÑUELA, E.; WLADBURGER, M.; WALTERSDORFER,A. Laboratory method to test effects of plant protection products on larvae of Chrysoperla carnea (Neuroptera: Chrysopidae). In: CANDOLFI, M. P.; BLUMEL, S.; FORSTER, R.; BAKKER, F. M.; GRIMM, C.; HASSAN S. A.; HEIMBACH, U.; MEADBRIGGS, M. A.; REBER, B.; SCHMUCK, R.; VOGT, H. (Ed.). Guidelines to evaluate side-effects of plant protection products to non-target arthropods. Reinheim: IOBC/ WPRS, 2000. p. 27-44.

VOGT, H.; RUMPF, S.; WETZEL, C.; HASSAN, S. A. A field method for testing effects of pesticides on the green lacewing Chrysoperla carnea Steph. IOBC/WPRS Bulletin, Gent, v. 15, n. 1, p. 176-182, 1992. 
ZANUNCIO, J. C.; MOURÃO, S. A.; MARTÍNEZ, L. C.; WILCKEN, C. F.; RAMALHO, F. S.; PLATA-RUEDA, A.; SOARES, M. A.; SERRÃO, J. E. Toxic effects of the neem oil (Azadirachta indica) formulation on the stink bug predator, Podisus nigrispinus (Heteroptera: Pentatomidae). Scientific Reports, London, v. 6, n. 1, p. $1-8,2016$.
ZAZYCKI, L. C. F. Diversidade de Coccinellidae em morangueiro e pessegueiro e biologia de três espécies em laboratório. 2010. Dissertação (Mestrado em Ciências) - Universidade Federal de Pelotas, Faculdade de Agronomia Eliseu Maciel, Pelotas. 